Рекомендована д. фрармац. наук, проф. В. В. Трохимчуком

УДК 615.454.2+616.147.17-007.64

DOI 10.11603/2312-0967.2018.1.8603

\title{
АНАЛІЗ ВІТЧИЗНЯНОГО ФАРМАЦЕВТИЧНОГО РИНКУ РЕКТАЛЬНИХ ЛІКАРСЬКИХ ЗАСОБІВ, ЩО ЗАСТОСОВУЮТЬСЯ ДЛЯ ЛІКУВАННЯ ПРОКТОЛОГІЧНИХ ЗАХВОРЮВАНЬ
}

\author{
() І. М. Олійник, С. М. Феденько, М. І. Федоровська \\ Івано-Франківський національний медичний університет \\ olijnyk.ivanna89@gmail.com
}

\begin{abstract}
Мета роботи. Вивчення номенклатури зареєстрованих в Україні ректальних лікарських засобів (ЛЗ) для лікування таких проктологічних захворювань, як геморой, анальна тріщина, проктити.

Матеріали і методи. Застосовано маркетинговий, статистичний та графічний аналізи.

Результати й обговорення. У ході досліджень встановлено, що на вітчизняному ринку представлено 34 найменування ректальних ЛЗ різних фрорм випуску, з яких $71 \%$ - супозиторії, $26 \%$ - мазі та 3 \% - креми; частка Л3 українського виробництва становить $35 \%$, а іноземного - 65 \%. Результати проведеного маркетингового аналізу свідчать, що актуальним і перспективним є створення нових вітчизняних ректальних лікарських засобів для застосування в проктології.

Висновки. Проведено маркетингове дослідження вітчизняного ринку ректальних лікарських препаратів, які застосовують у терапії проктологічних захворювань. Ректальні лікарські засоби були проаналізовані за країноювиробником, формою випуску, вмістом діючих компонентів та ціновою політикою. В результаті проведеного дослідження зроблено висновок, що асортимент вітчизняних ректальних лікарських препаратів, які застосовують в проктології, $є$ недостатнім, тому актуальною $€$ розробка нових, ефективних форм ректальних лікарських засобів для лікування проктологічних захворювань.
\end{abstract}

Ключові слова: проктологічні захворювання; геморой; ректальні лікарські засоби; фрармацевтичний ринок України.

Вступ. Геморой - це переважно судинна патологія клінічного (хірургічного) відхідникового каналу, зокрема нормальних печеристих утворень підслизового шару його слизової оболонки. Дуже важливим для розуміння патогенезу та методів лікування геморою $€$ те, що фрункціонально печеристі структури гемороїдальних вузлів термінального відділу прямої кишки є своєрідним гідравлічним механізмом: заповнюючись кров'ю і збільшуючись у розмірах, вони стискають складки слизової оболонки та герметизують відхідник [1]. Головними клінічними ознаками цієї групи захворювань $є$ ураження слизової оболонки прямої кишки різного ступеня тяжкості, яке супроводжується ознаками запалення, больовим синдромом, погіршенням місцевої мікроциркуляції [2].

За даними провідних колопроктологічних центрів, хірургічному лікуванню підлягають близько 30 \% хворих на хронічний геморой. Такі операції посідають перше місце в структурі хірургічних втручань будь-якого проктологічного відділення. Ускладнення після гемороїдектомії складає 30-40 \%, до яких належать виражений больовий синдром, кровотеча, дизуричні прояви, гнійно-запальні процеси. Терміни тимчасової непрацездатності після гемороїдектомії залишаються тривалими і складають не менше 4-х тижнів [1].
Консервативні методи лікування, включно найсучасніші препарати для медикаментозної терапії проктологічних захворювань, за ефективністю незначно перевищують плацебо. На сьогодні відомо про більше 30 різних методів хірургічного лікування хронічного геморою, анальної тріщини та проктиту, однак частота післяопераційних ускладнень та незадовільних результатів лікування залишається високою [3]. Лікування хронічних тріщин прямої кишки нині характеризується все більш частим використанням нехірургічних методів впливу на тонус внутрішнього анального сорінктера [4].

При виборі лікарських фрорм для профрілактики та лікування даних захворювань найбільш раціональною, зручною при застосуванні та здатною забезпечувати максимальний терапевтичний ефрект є фрорма супозиторіїв [5].

Медикаментозне лікування проктологічних захворювань на сьогодні залишається складним завданням проктології та фрармацевтичної технології, оскільки досі на фрармацевтичному ринку України кількість таких засобів обмежена.

Мета роботи - вивчення номенклатури зареєстрованих в Україні ректальних лікарських засобів (Л3) для лікування таких проктологічних захворювань, як геморой, анальна тріщина, проктити.

ISSN 2312-0967. Pharmaceutical review. 2018. № 1 
Фармацевтичний менеджмент, маркетинг та логістика Pharmaceutical management, marketing and logistics

Матеріали і методи. Протягом виконання роботи було проведено маркетингові дослідження ринку ректальних лікарських засобів, що застосовуються при проктологічних захворюваннях. В якості основного матеріалу дослідження використовувались дані Державного реєстру лікарських засобів, публікації у науковопрактичних виданнях, інфрормація з офріційних Webсайтів виробників. Отримані результати проілюстровані графрічно, з наведенням висновків та пояснень.

Результати й обговорення. Препарати проаналізували за такими групами АТС: препарати для лікування геморою та анальних тріщин у комбінації; інші засоби для лікування геморою та анальних тріщин для місцевого застосування; кортикостероїди; місце- ві анестетики; інші анаболічні препарати; різні речовини, що діють на травну систему та метаболізм; інші препарати, що сприяють загоєнню.

Отримані дані показали, що на вітчизняному ринку представлено 34 найменування ректальних Л3, що застосовуються для лікування проктологічних захворювань станом на грудень 2017 р.

У структурі асортименту проктологічних Л3 22 (65\%) препарати іноземного виробництва та 12 (35\%) - вітчизняного. Аналіз цінової політики (табл. 1) показав, що лікарські засоби імпортного походження $є$ дороговартісними, а отже, менш доступними для більшості населення. Поділ препаратів за країною-виробником наведено на рисунку 1.

Таблиця 1. Перелік проктологічних лікарських засобів, присутніх на фрармацевтичному ринку України*

\begin{tabular}{|c|c|c|c|c|}
\hline Код АТС & Назва препарату & Країна виробник & Форма випуску & Середня ціна, грн \\
\hline 1 & 2 & 3 & 4 & 5 \\
\hline C05A X03 & Прокто-глівенол® & $\begin{array}{c}\text { Рекордаті Індастріа Хіміка е } \\
\text { Фармасевтіка С.п.А., Італія }\end{array}$ & Крем & 132,15 \\
\hline C05A X03 & Прокто-Глівенол® & Дельфрарм Юнінг С.А.С. & Супозиторії & 140,44 \\
\hline $\mathrm{C05A} X$ & Реліфф & $\begin{array}{c}\text { Байєр Консьюмер Кер АГ, } \\
\text { Швейцарія }\end{array}$ & Мазь & 116,63 \\
\hline $\mathrm{C05A} X$ & Реліфф & $\begin{array}{c}\text { Байєр Консьюмер Кер АГ, } \\
\text { Швейцарія }\end{array}$ & Супозиторії & 111,70 \\
\hline C05A D03 & Реліф®Адванс & $\begin{array}{c}\text { Байєр Консьюмер Кер АГ, } \\
\text { Швейцарія }\end{array}$ & Супозиторії & 128,47 \\
\hline C05A D03 & Реліф®Адванс & $\begin{array}{c}\text { Байєр Консьюмер Кер АГ, } \\
\text { Швейцарія }\end{array}$ & Мазь & 159,47 \\
\hline C05A A & Реліф®Ультра & $\begin{array}{c}\text { Байєр Консьюмер Кер АГ, } \\
\text { Швейцарія }\end{array}$ & Супозиторії & 131,73 \\
\hline C05A X03 & Анузол & $\begin{array}{c}\text { ПАТ «Монфрарм», } \\
\text { Україна, Монастирище }\end{array}$ & Супозиторії & 15,90 \\
\hline C05A X03 & Анузол & $\begin{array}{l}\text { ВАТ «Нижсрарм», Російська } \\
\text { Федерація, Нижній Новгород }\end{array}$ & Супозиторії & 19,80 \\
\hline C05A X & Беладонни екстракт & $\begin{array}{c}\text { ПАТ «Монсрарм», } \\
\text { Україна, Монастирище }\end{array}$ & Супозиторії & 8,91 \\
\hline $\mathrm{C05A} X$ & Беладонни екстракт & $\begin{array}{c}\text { АТ «Лекхім-Харків», Україна, } \\
\text { Харків }\end{array}$ & Супозиторії & 12,07 \\
\hline C05A X & Красавки екстракт & $\begin{array}{l}\text { ВАТ «Нижфарм», Російська } \\
\text { Федерація, Нижній Новгород }\end{array}$ & Супозиторії & 14,28 \\
\hline $\mathrm{C05A} X$ & Бетіол® & АТ «Лекхім-Харків», Україна & Супозиторії & 12,58 \\
\hline C05A D & Гемороль® & $\begin{array}{c}\text { AT «Гербаполь», Польща, } \\
\text { Вроцлав }\end{array}$ & Супозиторії & 148,63 \\
\hline C05A X03 & Геморрон & $\begin{array}{c}\text { Фармасайнс Інк. } \\
\text { Канада, Монреаль }\end{array}$ & Мазь & 131,31 \\
\hline C05A X03 & Іхтіол & $\begin{array}{c}\text { ПАТ «Монфрарм», } \\
\text { Україна, Монастирище }\end{array}$ & Супозиторії & 14,90 \\
\hline C05A X03 & Іхтіол & $\begin{array}{l}\text { ВАТ «Нижфарм», Російська } \\
\text { Федерація, Нижній Новгород }\end{array}$ & Супозиторії & 22,16 \\
\hline C05A X & Постеризан® & $\begin{array}{l}\text { Др. Каде Фармацевтична } \\
\text { Фабрика ГмбХ, Німеччина }\end{array}$ & Мазь & 226,15 \\
\hline
\end{tabular}

ISSN 2312-0967. Фармацевтичний часопис. 2018. № 1 
Фармацевтичний менеджмент, маркетинг та логістика Pharmaceutical management, marketing and logistics

Продовження табл. 1

\begin{tabular}{|c|c|c|c|c|}
\hline 1 & 2 & 3 & 4 & 5 \\
\hline C05A X & Постеризан®Форте & $\begin{array}{l}\text { Др. Каде Фармацевтична } \\
\text { Фабрика ГмбХ, Німеччина }\end{array}$ & Мазь & 272,78 \\
\hline C05A X & Постеризан®Форте & $\begin{array}{l}\text { Др. Каде Фармацевтична } \\
\text { Фабрика ГмбХ, Німеччина }\end{array}$ & Супозиторії & 189,68 \\
\hline C05AD & Проктозан® & $\begin{array}{c}\text { СТАДА Арцнайміттель АГ, } \\
\text { Німеччина }\end{array}$ & Мазь & 130,18 \\
\hline C05AD & Проктозан®:Нео & $\begin{array}{c}\text { СТАДА Арцнайміттель АГ, } \\
\text { Німеччина }\end{array}$ & Мазь & 123,56 \\
\hline C05A X03 & Проктозан®Нео & Хемофрарм» АД, Сербія & Супозиторії & 131,57 \\
\hline C05AD & Анестезол® & $\begin{array}{c}\text { АТ «Лекхім-Харків», Україна, } \\
\text { Харків }\end{array}$ & Супозиторії & 16,18 \\
\hline C05A D05 & Новокаїн & $\begin{array}{c}\text { ПАТ «Монсрарм», } \\
\text { Україна, Монастирище }\end{array}$ & Супозиторії & 22,92 \\
\hline C05A D03 & Гемопрокт & Фармекс групп, ООО, Україна & Супозиторії & 37,50 \\
\hline $\mathrm{A} 16 \mathrm{~A} X$ & Обліпихова олія & $\begin{array}{l}\text { ВАТ «Нижфарм», Російська } \\
\text { Федерація, Нижній Новгород }\end{array}$ & Супозиторії & 24,80 \\
\hline $\mathrm{A} 16 \mathrm{~A} \times 10$ & Обліпихова олія & АТ «Лекхім-Харків» & Супозиторії & 19,50 \\
\hline D03A X16 & Метилурацил & $\begin{array}{l}\text { ВАТ «Нижфарм», Російська } \\
\text { Федерація, Нижній Новгород }\end{array}$ & Мазь & 37,05 \\
\hline A14 B & Метилурацил & $\begin{array}{l}\text { ВАТ «Нижфрарм», Російська } \\
\text { Федерація, Нижній Новгород }\end{array}$ & Супозиторії & 25,30 \\
\hline A14B & Метилурацил & $\begin{array}{c}\text { АТ «Лекхім-Харків», Україна, } \\
\text { Харків }\end{array}$ & Супозиторії & 11,27 \\
\hline A14B & Метилурацил & $\begin{array}{c}\text { ПАТ «Монфрарм», } \\
\text { Україна, Монастирище }\end{array}$ & Супозиторії & 11,50 \\
\hline A14B & $\begin{array}{l}\text { Метилурацил- } \\
\text { Фармекс }\end{array}$ & Фармекс групп, ООО, Україна & Супозиторії & 12,40 \\
\hline D03AX & $\begin{array}{c}\text { Метилурацил } 3 \\
\text { мірамістином }\end{array}$ & $\begin{array}{c}\text { ПрАТ «Фармацевтична фрірма } \\
\text { «Дарниця», Україна }\end{array}$ & Мазь & 45,60 \\
\hline
\end{tabular}

Примітка: * - станом на грудень 2017 р.

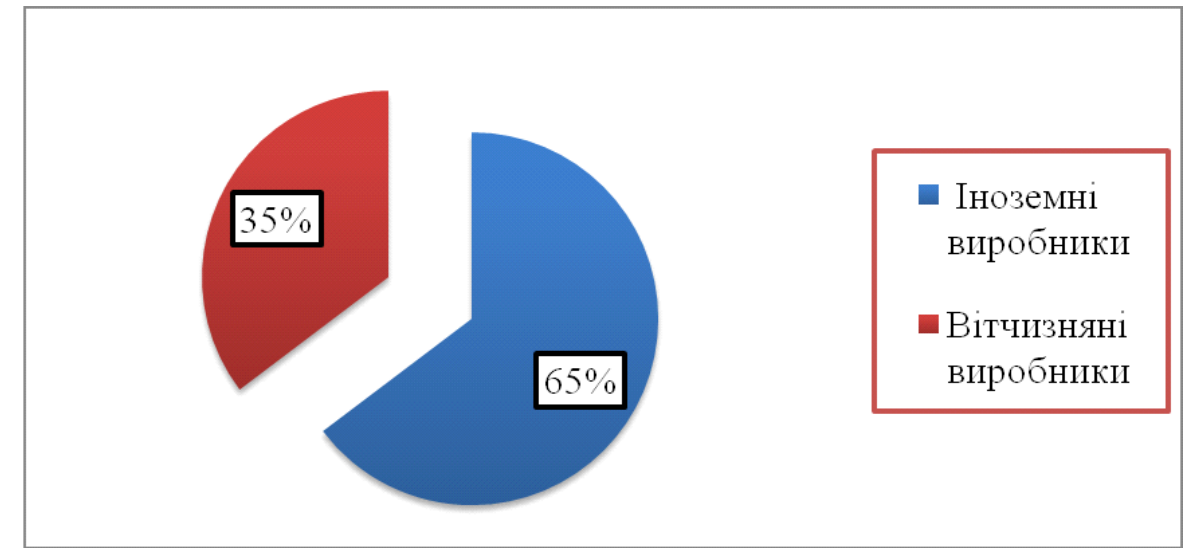

Рис. 1. Співвідношення ректальних лікарських засобів іноземного та вітчизняного виробництва, що застосовують при лікуванні проктологічних захворювань.

Вітчизняними виробниками аналізованих лП є: АТ «Лекхім-Харків», ПрАТ «Фармацевтична фрірма «Дарниця», ПАТ «Монфрарм», ТзОВ «Фармекс груп». Про- позиції на орармацевтичний ринок надходять також 3 п'яти країн світу (Швейцарії, Польщі, Німеччини, Сербії, Російської Федерації).

ISSN 2312-0967. Pharmaceutical review. 2018. № 1 
Фармацевтичний менеджмент, маркетинг та логістика Pharmaceutical management, marketing and logistics

Асортимент ректальних ЛЗ представлений такими лікарськими фрормами: супозиторії - 71 \%, мазі $26 \%$ та креми - $3 \%$ (рис. 2).

Встановлено, що найбільш розповсюдженою лікарською фрормою $є$ супозиторії.

Аналізуючи дані, наведені на рисунку 3, варто зазначити, що частка наявних лікарських засобів у фрормі супозиторіїв українського виробництва становить 45,8 \%, а іноземного - 54,2 \%. Результати порівняння вартості вітчизняних та імпортних супозиторних лікарських фрорм (табл. 1) дозволяють стверджувати, що супозиторії іноземного виробництва $€$ значно дорожчими від українських, тому створення нового ЛЗ у фрормі супозиторіїв для лікування про- ктологічних захворювань є актуальним завданням фрармацевтичної науки і практики.

Дослідивши препарати за складом діючих речовин із використанням класифрікаційної системи АТС, встановлено, що супозиторії представлені такими фрармакотерапевтичними групами: C05A X (інші засоби для лікування геморою та анальних тріщин для місцевого застосування) - 12 найменувань, C05A D (місцеві анестетики) - 5, А14В (нестероїдні препарати) - 4, A16A X (різні речовини, що діють на травну систему та метаболізм) - 2 та C05A A (кортикостероїди) - 1 найменування відповідно. Для більш детального аналізу супозиторії були продиференційовані в межах кожної групи за походженням діючої речовини (рис. 4).

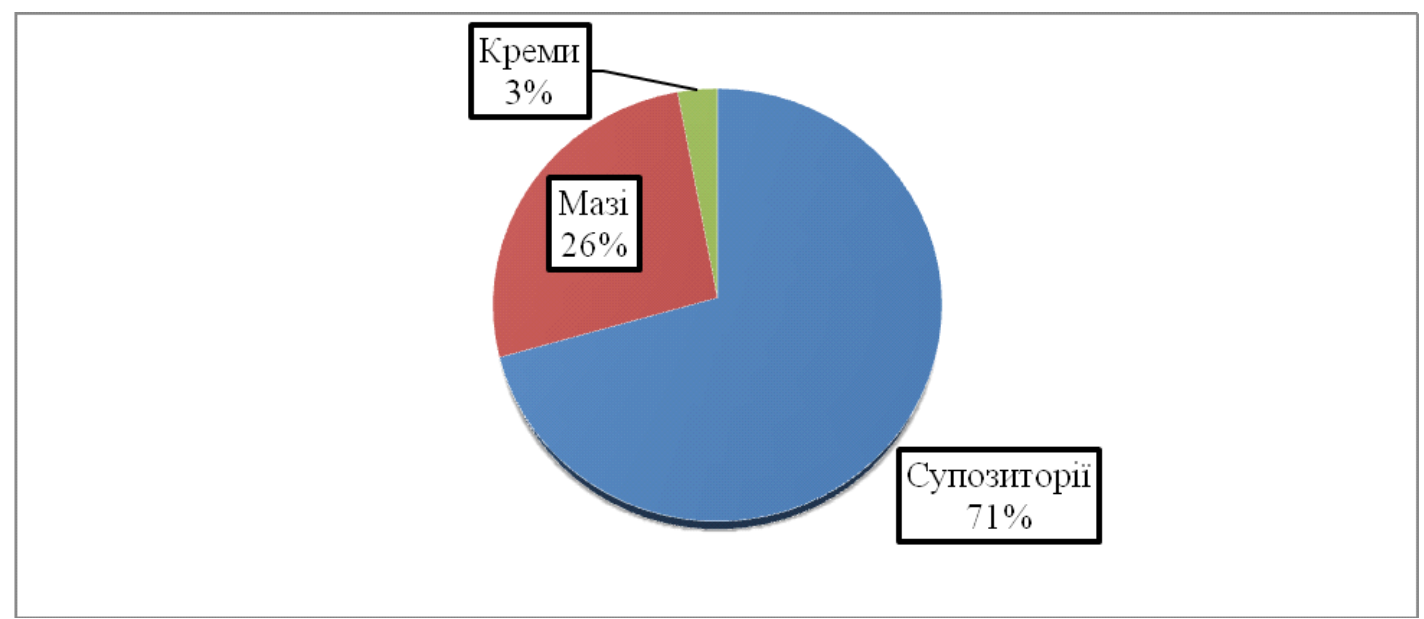

Рис. 2. Аналіз ректальних лікарських засобів, що використовують для лікування проктологічних захворювань, за орормами випуску.

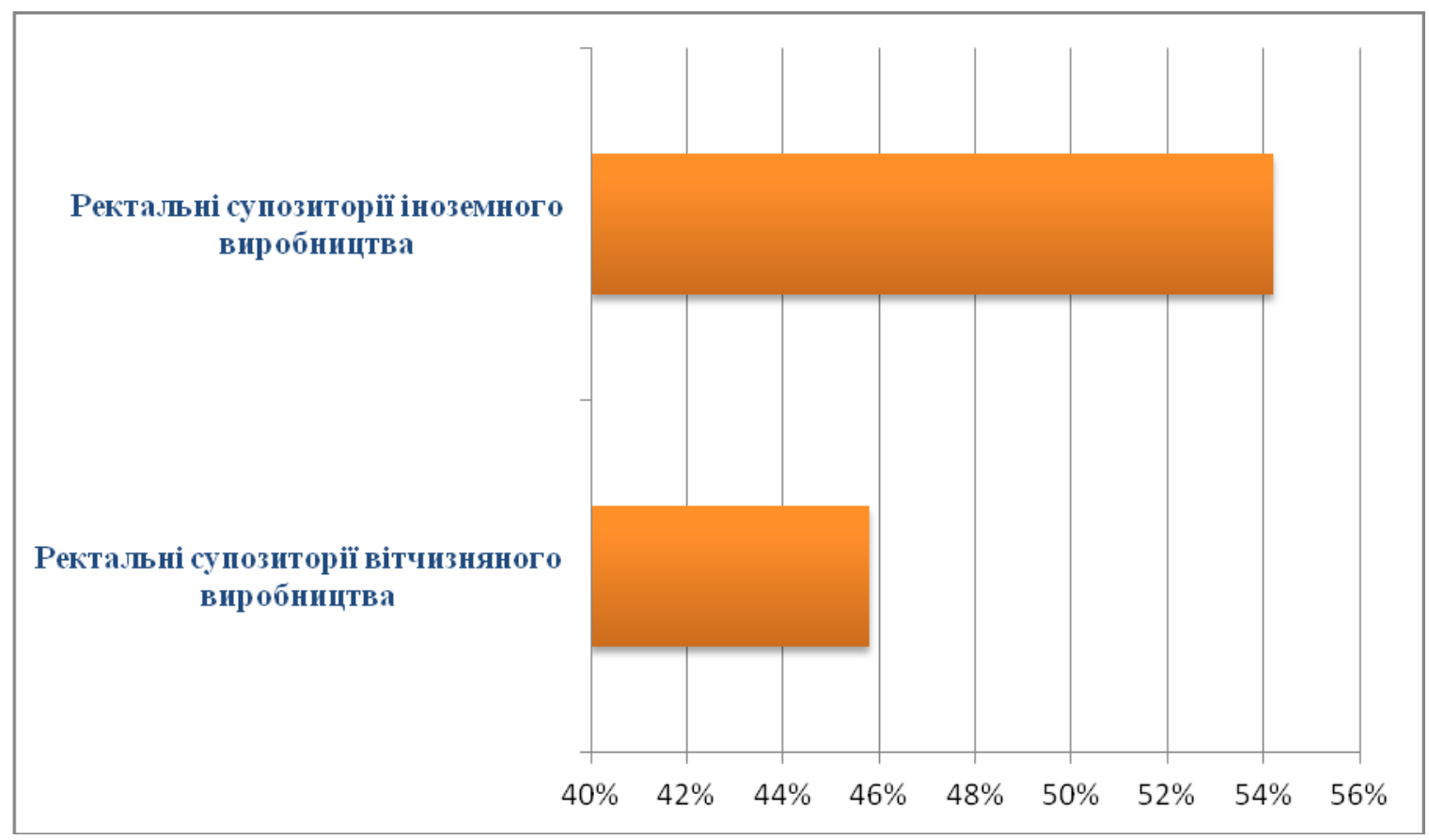

Рис. 3. Співвідношення ректальних супозиторіїв іноземного та вітчизняного виробництва, що застосовують при лікуванні проктологічних захворювань.

ISSN 2312-0967. Фармацевтичний часопис. 2018. № 1 
Фармацевтичний менеджмент, маркетинг та логістика Pharmaceutical management, marketing and logistics

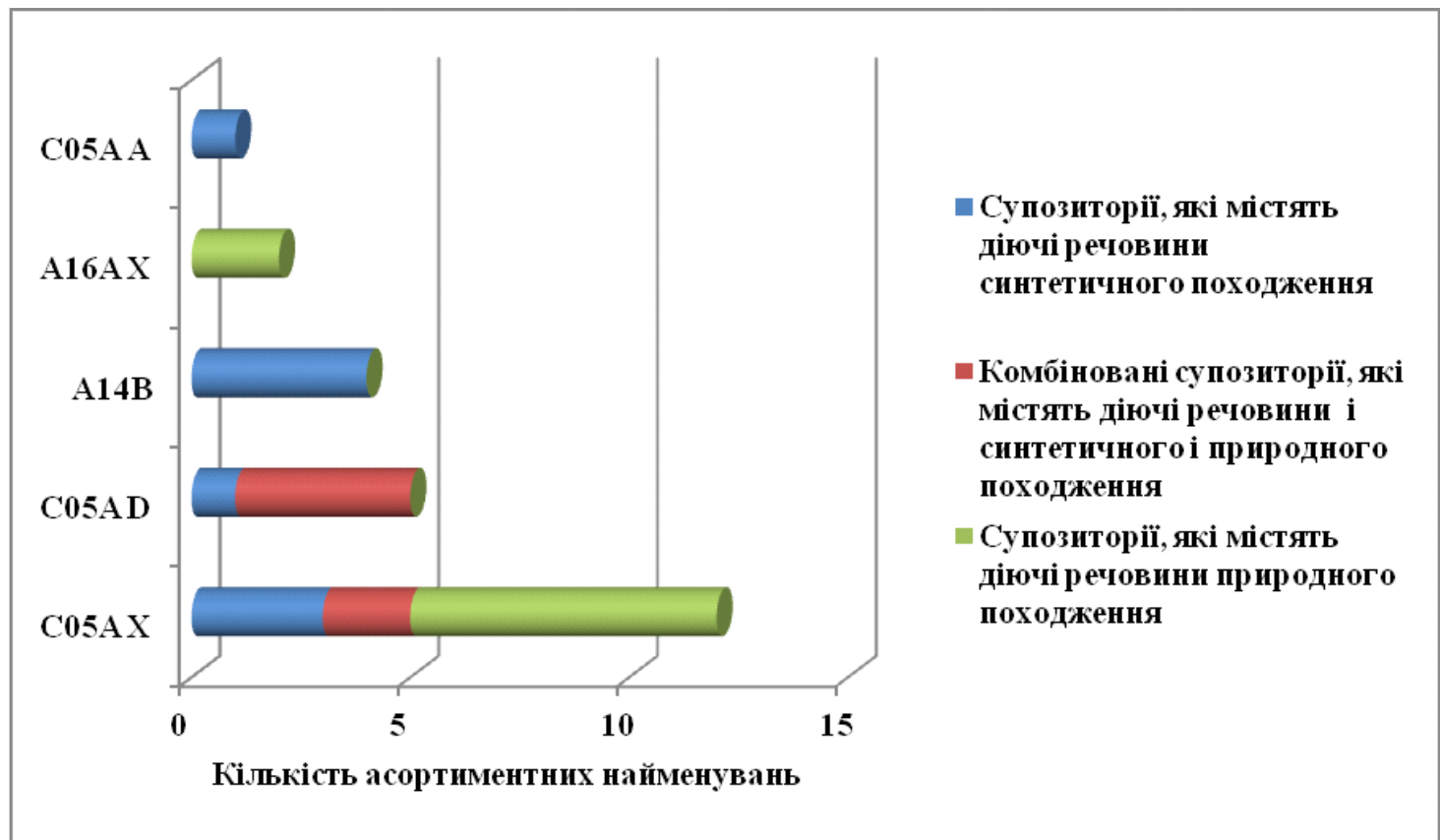

Рис. 4. Аналіз асортименту ректальних супозиторіїв згідно з класифрікаційними групами АТС з врахуванням походження діючих речовин.

За результатами проведеного дослідження встановлено, що частка супозиторних лікарських фрорм із діючими речовинами природного походження становить 37,5 \%, $25 \%$ - комбіновані препарати (містять речовини природного і синтетичного походження) та 37,5 \% прийшлось на препарати з речовинами синтетичного походження. Проаналізуваши супозиторії за складом діючих речовин, виявлено, що найменшим $є$ асортимент комбінованих препаратів, терапевтичний ефект яких забезпечується поєднанням речовин природного та синтетичного походження.

Висновки. Проведено аналіз асортименту ректальних лікарських засобів, представлених на фрарма- цевтичному ринку України, які використовують при медикаментозній терапії проктологічних захворювань. У ході досліджень встановлено, що частка лз закордонного походження становить $65 \%$, що значно перевищує кількість препаратів вітчизняного виробництва.

Дослідивши ректальні лікарські засоби за країною виробником, формою випуску, вмістом діючих компонентів та ціновою політикою, ми дійшли висновку, що асортимент вітчизняних ректальних супозиторіїв, які застосовують в проктології, є недостатнім, тому актуальною є розробка нових, сучасних ректальних супозиторних фрорм для лікування проктологічних захворювань.

\section{АНАЛИЗ ОТЕЧЕСТВЕННОГО ФАРМАЦЕВТИЧЕСКОГО РЫНКА РЕКТАЛЬНЫХ ЛЕКАРСТВЕННЫХ СРЕДСТВ, ПРИМЕНЯЕМЫХ ДЛЯ ЛЕЧЕНИЕ ПРОКТОЛОГИЧЕСКИХ ЗАБОЛЕВАНИЙ}

\section{И. М. Олийник, С. М. Феденько, М.И.Федоровская}

Ивано-Франковский национальный медицинский университет

olijnyk.ivanna89@gmail.com

Цель работы. Целью нашего исследования было изучение номенклатуры зарегистрированных в Украине ректальных лекарственных средств (ЛС) для лечения таких проктологических заболеваний, как геморрой, анальная трещина, проктиты.

Материалы и методы. Использован маркетинговый, статистический и графрический анализы.

Результаты и обсуждение. В ходе исследований установлено, что на отечественном рынке представлено 34 наименования ректальных ЛС различных форм выпуска, из которых $71 \%$ - суппозитории, $26 \%$ - мази и $3 \%$ кремы; доля ЛС украинского производства составляет 35 \%, а иностранного - 65 \%. Результаты проведенного маркетингового анализа свидетельствуют, что актуальным и перспективным является создание новых отечественных ректальных лекарственных средств для применения в проктологии.

Выводы. Проведено маркетинговое исследование отечественного рынка ректальных лекарственных

ISSN 2312-0967. Pharmaceutical review. 2018. № 1 
Фармацевтичний менеджмент, маркетинг та логістика

Pharmaceutical management, marketing and logistics

препаратов, применяемых в терапии проктологических заболеваний. Ректальные лекарственные средства были проанализированы по странам-производителям, фрорме выпуска, содержанием действующих компонентов и ценовой политикой. В результате проведенного исследования сделан вывод, что ассортимент отечественных ректальных лекарственных препаратов, применяемых в проктологии, недостаточен, поэтому актуальной является разработка новых, эфрфективных фрорм ректальных лекарственных средств для лечения проктологических заболеваний.

Ключевые слова: проктологические заболевания; геморрой; ректальные лекарственные средства; фрармацевтический рынок Украины.

\title{
ANALYSIS OF THE DOMESTIC PHARMACEUTICAL MARKET OF RECTAL DRUGS USED FOR TREATMENT OF PROCTOLOGIC DISEASES
}

\author{
I. M. Oliynyk, S. M. Fedenko, M. I. Fedorovska \\ Ivano-Frankivsk National Medical University \\ olijnyk.ivanna89@gmail.com
}

The aim of the work. Studying the nomenclature of rectal drugs registered in Ukraine (Medicinal Products) for the treatment of proctologic diseases, such as hemorrhoids, anal fissures, and proctitis.

Materials and Methods. Marketing, statistical and graphical analyzes.

Results and Discussion. During research it was established that 34 names of rectal drugs (RD) in different dosage forms were presented in the domestic market, of which $71 \%$ were suppositories, $26 \%$ - ointments and $3 \%$ - creams; the share of RD of Ukrainian production was $35 \%$ and foreign $-65 \%$. The results of the marketing analysis show that the development of new domestic rectal drugs for use in proctology is actual and prospective.

Conclusions. The marketing research of the domestic market of rectal drugs used in the treatment of proctologic diseases was conducted. Rectal drugs were analyzed by country of origin, dosage forms, content of active ingredients and price policy. As a result of the research, it was concluded that the range of domestic rectal drugs used in the proctology was not sufficient. So, the development of new, effective dosage form of RD for the treatment of proctologic diseases is important.

Key words: proctologic diseases; hemorrhoids; rectal drugs; the pharmaceutical market of Ukraine.

\section{Список літератури}

1. Чобей С. М. Використання біофлавоноїдів у комплексному лікуванні геморою / С. М. Чобей // Науковий вісник Ужгородського університету, серія «Медицина». 2015. - № 1(51). - С. 173-177.

2. Яковлева Л. В. Дослідження механізму протизапальної дії нової вітчизняної мазі «Естан» на різних моделях гострого запалення / Л. В. Яковлева, К. П. Бездітко // Клінічна фрармація. - 2008. - № 3. - С. 30-34.

3. Ісртодій А. Г. Критерій ефрективності лікування хворих на хронічні ускладнені анальні тріщини / А. Г. Іортодій, І. М. Козловська, О.В.Білик // Вісник ВДНЗУ «Українська

\section{References}

1. Chobei SM. [Complex treatment of hemorrhoids using bioflavonoids]. Naukovyi visnyk Uzhhorodskoho universytetu, seriia «Medytsyna». 2015;1(51): 173-7. Ukrainian.

2. Yakovleva LV, Bezditko KP. [Investigation of the mechanism of anti-inflammatory action of the new domestic ointment «estan» on different models of acute inflammation] Klinichna farmatsiia. 2008; 30-4. Ukrainian.

3. Iftodii AH, Kozlovska IM, Bilyk OV. [Efficiency criteria for evaluating treatment of patients with chronic complicated медична стоматологічна академія». - 2013. - № 4(44). C. 22-25.

4. Conservative versus surgical treatment for chronic anal idiopathic fissure: a prospective randomized trial / M. Rosa, G. Cestaro, C. Vitiello [et al.] // Updates Surg. - 2013. Iss. 65 (3). - P. 197-200.

5. Дослідження впливу природи і складу основи на вивільнення сукцифенату та діакамфу із супозиторіїв / Н. А. Кондратюк, В. О. Грудько, Д. І. Дмитрієвський, С. І. Мерзлікін // Вісник фрармації. - 2008. - № 2(58). C. $52-55$

anal fissure]. Visnyk VDNZU «Ukrainska medychna stomatolohichna akademiia». 2013;4(44): 22-5. Ukrainian.

4. Rosa M, Cestaro G, Vitiello C. Conservative versus surgical treatment for chronic anal idiopathic fissure: a prospective randomized trial. Updates Surg. 2013;65(3): 197-200. 5. Kondratiuk NA, Hrudko VO, Dmytriievskyi DI, Merzlikin SI. [Investigation of the influence of the base's nature and composition on releasing of succiphenate and diacamph from suppositories]. Visnyk farmatsii. 2008;2(58): 52-5. Ukrainian. 